\title{
"The New Deal of War"
}

By Torbjørn Sirevåg

University of Oslo

Half a year beforeJapanese pilots bombed the United States into World War II, in a June 1941 edition of Coronet magazine, a little known author added his voice to that of other critics of the policies of Franklin D. Roosevelt. There were basically only two New Deals, John Pritchard here retorted to those who were debating the many twists and turns of the administration's policies. As he saw it, there had been a visionary and planning-oriented first stage - a "New Deal I" - from 1933 to the Nazi push into Holland in May 1940. Roughly at that time, however, the first stage had given way to a far more hardnosed phase which he labeled "New Deal II - the New Deal of War."

If Pritchard's phrase was new, the notion behind it was not. But his was and remains the most poignant expression of an attitude that for all its impact has never been fully understood. How can it be that even if a clear majority of the American people favored all steps short of war in the months immediately before Pearl Harbor the President hesitated to take the lead ?And how can it be explaineed that Washington remained in a state of political turmoil during most of the military emergency when other nations at this crucial moment set aside politics in a show of real national unity? In both situations, the corrosive influence of the "New Deal of War" idea remains crucial.

In retrospect, this idea served the function as a bridge uniting the peacetime and wartime opposition against Roosevelt. It contained a conspiratorial theory of war and reform that appeared to make both phenomena part of the same administration grand design. As a result, the same war which saddened American reformers because they regarded it as the final farewell to reform horrified many of Roosevelt's opponents precisely because they saw in it the very culmination of a New Deal whose essence they believed to be regimentation. Bizarre though the "New Deal of War" notion may 
strike present-day observers, it was by no means shared only by the lunatic fringe. As it had wide currency not only among important Republicans in and out of Congress but also among leading Democratic dissidents, the term "fringe" is misleading. It is high time, therefore, to examine somewhat more closely the yeast that fomented so much frenzied opposition against FDR in the years immediately before and after Pearl Harbor.

This entails first of all a closer look at Roosevelt's connection with the phenomenon called isolationism. American isolationism in the nineteen thirties was no less than a conglomeration of approaches and attitudes. It was in part a geographic impulse, a sense of complacency nurtured by the fact that the dangerous world was thousands of miles away. On the other hand, isolationism was in Samuel Lubell's words also ethnic and emotional rather than geographical; Irish-Americans, German-Americans and Italian-Americans sought to keep the United States from committing itself to a policy that might harm the interests of their old countries. But perhaps above all, isolationism reflected simply the old American viewpoint that "Europeans are a different breed of cats from us" and the companion view that the United States had a special mission in the world that it might forfeit by aligning itself with the troubled nations directly. As Henry Clay had put it, America must keep the lamp burning lightly on the western shore rather than risk extinction amid the ruins of falling European republics. Among the major isolationist impulses there was finally the disillusionment following in the wake of the First World War, highlighted by the exposures in the mid-thirties of the activities of greedy munitions makers. Added to all this came the impact of the great depression itself with its understandable urge to concentrate attention on the home front and, in the words of the new President of the United States, "putting first things first."

In view of what later happened, Roosevelt's initial attitude is important. His true convictions are hard to determine. Scholars like Basil Rauch have argued persuasively that he was an internationalist at heart. Others argue with Robert Divine that Roosevelt pursued an isolationist policy "out of genuine conviction." Still others, like Langer and Gleason, find it impossible to penetrate and determine the President's outlook and reasoning. Indications are that Roosevelt may have been instinctively internationalist but that as an equally instinctive politician he trimmed not only his policies but his convictions to the wind. As Hoover's Secretary of State, 
Henry L. Stimson, found to his delight in the winter of 1932 - 33, Roosevelt took a much more activist and internationalist approach to the problem of Japan than could have been expected. On the other hand, a belligerent stand with regard to Pacific matters could be acceptable even to traditional American isolationists; "It is not nearly so dangerous a prospect," the isolationist Senator Robert Taft was to tell the National Republican Club in 1940, "that we may become involved in a war in the Pacific as in the European war." In late 1934 Roosevelt appeared to have made a genuine attempt to win congressional approval for U.S. membership in the World Court, only to see the proposal defeated in early 1935. And when the President later that year wrote his ambassador to Germany a personal letter, he couched his words in distinctly isolationist terms, "I do not know that the United States can save civilization but at least by our example we can make people think and give them the opportunity of saving themselves."

The important point in this connection, however, is not what Roosevelt really thought. Rather, it is the impression which he gave the American nation. Nothing in Roosevelt's early foreign policy indicated bold internationalism. In fact, when candidate Roosevelt in 1932 renounced the idea of American membership in the League of Nations to woo the support of the isolationist newspaper magnate William Randolph Hearst, it was an action that soon appeared rather in style. The reciprocal trade agreements policy inaugurated in 1934, however internationalist in its long-range aims, was caution incarnate. Roosevelt's torpedoing of the London International Economic Conference in June 1933, however, had been hailed as a "new Declaration of Independence." The diplomatic recognition of Soviet Russia in 1933 and the Good Neighbor policy toward Latin America were not regarded as signs of new internationalism, but meant simply that the United States had abandoned a policy of involvement for one of normalcy and benign laissez-faire.

The President appeared not only to accept the neutrality legislation enacted between 1935 and 1937; he actively pushed for it. The First Neutrality Act, which created a mandatory embargo on implements of war to belligerent parties, was signed by Roosevelt on August 31, 1935. It was renewed the following year and made permanent and expanded in the spring of 1937 when U.S. citizens were forbidden to sail on belligerent ships while the President of the United States was given wide discretionary powers to stop the export of certain materials other than war materials. The 1937 act also 
introduced the "cash and carry" system to avoid American war profiteering. Secretary of State Hull had opposed neutrality legislation. Roosevelt, however, had discussed taking profits out of war with the Nye committee and personally urged its members to formulate proposals. The Nye committee had not meant to consider neutrality plans until the President had prodded them in that direction, the chief investigator of the committee, Stephen Rauschenbush, informed the State Department in March of 1935. At Chatauqua, in his only foreign policy speech during the 1936 campaign, Roosevelt played heavily on the "merchants of death" theme. "We must decide which we love more," a supporter had just written him, "- dollars or lives." At Chatauqua, the President insisted that "the Nation will answer-must answer - 'we choose peace.' "'

Important New Deal advisers underlined the impression that Roosevelt's administration was indeed more committed to nationalism than to internationalism. Men like Raymond Moley, Rexford Tugwell and Donald Richberg were all in favor of what Richberg termed "an economic policy of national self-sufficiency." Even Secretary of Agriculture Wallace, who in 1934 had chartered a middle course between nationalism and internationalism that impressed Henry L. Stimson greatly, seemed decidedly to prefer the former. In his pamphlet America Must Choose, Wallace argued that sooner or later tariffs must be lowered greatly and international trade expanded, but his emphasis in the Department of Agriculture was clearly on such a new course-later.

The cumulative result of all this was the feeling that there had emerged an American consensus, shared emphatically by the White House, that neutrality was the only acceptable policy. John T. Flynn and Charles A. Beard, both liberals and isolationists, were convinced that Roosevelt at this stage was in their camp. Governor Landon of Kansas believed by January 1938 that his adversary in the 1936 election was himself largely responsible for bringing isolationism to a climax because of his playing around with leftist elements. With some exaggeration, but also a substantial element of truth, Landon later remarked, "No one was more isolationist than Roosevelt in his first administration." In contrast to the embattled domestic policies of the Roosevelt administration, the President's foreign policy was granted considerable goodwill during his first period in office- what could be termed Phase One of New Deal foreign policy.

Phase Two began abruptly in the autumn of 1937 . No sooner had 
the isolationist consensus been stabilized than it was superseded by violent controversy. During the first phase, the world had witnessed German rearmament, Mussolini's invasion of Ethiopia and the emerging fascist movement in Spain. In July 1937, even more ominously, Japan pushed into Northern China, and there were signs of an alliance between Tokyo and Berlin in September. Asked to dedicate the Outerlink bridge over the mouth of the Chicago river, Roosevelt chose the occasion to make what later became known as his "Quarantine" speech of October 5, 1937. In the midst of the isolationist heartland, the President declared that the interdependence of the world now made isolationism impossible. He pointed to a spreading epidemic of world lawlessness, and he asked his listeners to note that "when an epidemic of physical decease starts to spread, the community approves and joins in a quarantine of the patients in order to protect the spread of the contagion." Moving beyond his Chatauqua speech, Roosevelt stated that America could no longer remain content to merely hope for peace but that it would have to actively engage in the search for it.

The nation responded to the speech with mixed reactions. Among the Washington politicians, however, the response was in the opinion of Secretary Hull and presidential adviser Rosenrnan "quick and violent - and nearly unanimous. It was condemned as warmongering and saber-rattling." If Roosevelt had erred by boosting the isolationist cause during his first administration, it seemed he had now overreacted in the opposite direction. The Secretary of State, who had not been consulted, believed it had set the internationalist cause back at least six months. The speech came at a singularly inopportune moment hard 'on the heels of the Supreme Court fiasco. The Supreme Court fight had opened a Pandora's box of domestic political troubles for the administration; the "quarantine" speech had a similar effect in the foreign policy debate. Politics would hereafter contaminate foreign and domestic affairs alike.

Congress had sought to eliminate presidential discretionary powers already by the Neutrality Act of 1935, at the apex of Roosevelt's isolationism. After 1937, it redoubled its efforts. In January 1938, the administration barely managed to head off passage of the Ludlow amendment which proposed to change the U.S. constitution so that a declaration of war would become possible only after a national referendum-except in case of invasion. The more critical the world situation became-and the majority of Americans were not fooled by the mood of optimism that swept the continent 
in the wake of Munich - the more determined Congress was to restrain the President. Roosevelt's request for a special congressional session to repeal the arms embargo after Hitler's invasion of Poland in September 1939 met with an uproar. The resulting Neutrality Act of 1939 was a compromise that repealed the embargo, but retained so many restrictions that it was tantamount to one more isolationist victory. It took a vicious debate before the President's request for selective service legislation became law in the autumn of 1940. Nor did Roosevelt's reelection in 1940 remove the question of war and peace from politics. After he had asked Congress to pass the Lend-Lease bill in January 1941, Washington, in the words of a Herbert Hoover associate, "has forgotten National Unity and is engaged in a battle over the Lend-Lease bill, which is surcharged with bitterness and explosive invective." Should the United States become wrecked as a nation, Senator Arthur Vandenberg wrote in his diary, "you can put your finger on this precise moment as the time when the crime was committed." While Lend-Lease did become law on March 11, 1941, it did so over the objections of what seemed to be an increasingly frenzied opposition.

The intense hostility in congressional and Republican circles stood in marked contrast to the growing willingness of the American people to back Roosevelt's foreign policy. In 1939, Americans for the first time had come to regard the question of war and peace as more important than employment. That year, a "tremendous upsurge" in public sentiment began to favor the cause of the western democracies. By September, 62 percent favored a revision of the neutrality laws. In October, a majority of Americans had been unwilling to allow the United States to loan money to the democracies, but by March of 1940 that, too, had changed. In the middle of that summer, the nation was overwhelmingly for military conscription. This was in part a reflection of the nation's "immense enthusiasm" for defense by 1939-40. At the time of the LendLease proposal, moreover, more than 60 percent of all Americans questioned by pollsters favored aiding Britain even at the clear risk of war. As one prominent Republican pointed out to another, it would be almost impossible to deny Roosevelt the legislation he was seeking.

It testifies to the intenseness of their opposition when many legislators nevertheless continued to defy the President. By 1939, Congress and the nation were parting ways, and the lawmakers knew it. "I know that the sentiment of the people of North Carolina 
is for revision of the Neutrality Act," Senator Josiah Bailey wrote in September, "but we must not be governed in a matter of this sort by public sentiment." Many of those who reluctantly came out in favor of the administration's foreign policy did so only out of fear of political extinction, a fact that did not lessen their anger. The very fact that Americans on the whole were by $1940-41$ ready to dispense with the traditional policy of isolation seemed to spur a highly vocal minority into even intensified isolationism such as typified by the "America First" movement.

Those who have criticized Roosevelt for his temerity at the time, pointing to his substantial backing from the nation, have often failed to realize the full extent of his predicament. It was the antagonism of this rather minor but select group of opponents that gave Roosevelt the feeling, of which he complained in late 1939, that "I am almost literally walking on eggs," and which prompted him to begin - in Professor Patterson's phrase - "eating humble pie" in order to win a more widespread congressional support for his foreign policy.

The basis of such extraordinary dissent was clearly traditionally isolationist- the conviction that in spite of the menacing world situation, the United States was not really threatened. It followed from this that the administration's danger warnings had to be dismissed as warmongering. That, in turn, meant that the real threat was domestic more than foreign. Senator William E. Borah set the ratio at 90 percent domestic compared to 10 percent foreign. And an Iowa Republican, Verne Marshall, summarized the viewpoint: "Ours is an internal crisis, seriously aggravated by external complications." Isolationism had never been far removed from party politics, and in Congress it turned at the end of the nineteen thirties into partisanship of the highest order, becoming an integral part of the crusade against Roosevelt and his New Deal.

In foreign policy matters as in domestic affairs the key word was suspicion. Critics of all political persuasions seemed to agree that Roosevelt devoted his energies to the manufacture of war clouds. His motives, by common agreement, were deceptive and political: to secure a third term nomination and prolong the New Deal. His means: the smoke screen of emergency or even actual war. Neither did there seem to be much doubt as to what the President's reasons were for his allegedly new foreign policy attitude - troubles at home. Socialist leader Norman Thomas reasoned that the New Deal had failed to conquer the problem of poverty and insecurity and was 
taking the nation to war partly to compensate for this failure. The Socialist party - and leftist critics like Charles A. Beard-took the line that Roosevelt was seeking an escape in a big war trade or indeed in warfare. Beard later elaborated upon a Saturday Evening Post editorial which quoted the dying King Henry IV's cynical advice to his son: "Be it thy course to busy giddy minds/ With foreign quarrels; that action, hence borne out/ May waste the memory of the former days." True to his name, Maury Maverick, a Texas New Dealer, protested openly, "We Democrats have got to admit that we are floundering. The reason for all this battleship and war frenzy is coming out: we have pulled all the rabbits out of the hat and there are no more rabbits." The conservative approach was much the same. General Robert E. Wood, chairman of America First, remained convinced that Roosevelt used the war as a way out. So was Amos Pinchot, the one-time progressive who in the middle thirties had turned conservative with a vengeance. The critics seemed to have no doubt but that Roosevelt, after having failed on the "low" road to power and prosperity through domestic reforms, was by 1937 willing to take the "high" road of international conflict to reach the goal. They all kept coming back to it, the editors of the Post said about the "quarantine" speech, "because it is the key to much of what has happened since."

What might be called the anti-Roosevelt version of isolationism drew nourishment from a number of related concepts and occurrences. Orson Welles' famed 1938 broadcast which purported to bring news about a Martian invasion had its peculiar impact also in politics. Roosevelt, according to the critics, was more skilled than Welles in creating a scare to give him what he wanted-more presidential power. To Norman Thomas, such was logical thinking because the very lack of immediate danger from abroad "will make it more necessary for artificial propaganda and regimentation to maintain the war spirit." When the President declared a national emergency in February 1939, this was simply taken as an indication "that he is in a bad frame of mind." A characteristically flippant remark made by the President upon returning to Washington from Warm Springs after a vacation in April 1939 - "T'll be back in the fall if we don't have a war" - aroused much speculation. Roosevelt's boast from 1935 that contrary to the charges that the New Deal was drifting helplessly, each step had a definite relationship to every other step "because we planned it that way," now returned to haunt him. The implication was, as Frank Knox made clear in his 1938 
book We Planned It That Way, that the nation's new predicament was part of New Deal planning. Critics who had previously refused to find consistency in the President's actions were now disposed to regard such an idea as gospel truth.

Throughout his Presidency, Franklin D. Roosevelt had faced grave decisions and difficult times, but it seemed as if crisis had served only to strengthen the tie between the President and the American people. Noting this, Roosevelt's critics were quick to confuse necessity with intention, thus reversing cause and effect by arguing that there was crisis precisely because the New Deal wanted and needed it. It was important in this connection that under the New Deal, war and reform had been so to speak ideological brothers from the outset. Launching his program in 1932, Roosevelt had declared it a "call to arms." In his inauguration address he threatened that he might be forced to ask for powers that matched those he would command in case of actual warfare. Indeed, as Professor Leuchtenburg has pointed out, the New Deal was resting its case on an analogy between depression and wartime emergencies. What could be more intrinsically in line with New Deal policy than war?

Nearly all of Roosevelt's foreign policy critics regarded the President's personality as the real danger. Even admirers took note of Roosevelt's consummate ability to shift the nation's attention from one field to another. Most opponents - and many apparent backers - seemed to agree with Charles A. Lindbergh that Roosevelt could persuade himself that anything he desired would be in the nation's interest. Norman Thomas was convinced that there was a relationship "between Roosevelt's growing Messianic complex and his conception of the emergency," although he refrained from saying so in public. The Republican party, Alf Landon reported, was being pushed into isolationism, "step by step, by the subconscious fear of Roosevelt." A chief organizer of the internationalist Willkie movement, Willard Archie, agreed that there was fear also in his group of a President who merely worked on people's feelings and whose foreign policy remained always a secret. The crux of the whole situation, Herbert Hoover believed, was the profound distrust in his successor. He was convinced that if any one of the nation's previous 31 presidents had made a request for neutrality revision such as Roosevelt did in 1939, the bill would have been passed immediately. Together with the opportunities offered by a major crisis Roosevelt's alleged extreme opportunism would make an explosive combination. 
What seemed to render the destruction of the republic inevitable, however, was the widespread conviction that war would by its own inexorable logic lead to the death of democracy and replace it with dictatorship. It was no new concept; in fact, both European and American intellectuals had long drawn attention to it. It had been Werner Sombart's thesis in 1913 that capitalism in its extreme form had developed under the impetus of war. Prior to Pearl Harbor, a symposium headed by Professor Willard Waller concluded that the impact of war on the nation's institutions would be nothing short of devastating. Another scholar, Frederick J. Teggart, pointed out that while the "War-State" would be organized for the prosecution of war, the reverse would also be true: "In every country the prosecution of war calls the War-State into being." Bronislaw Malinowski, the famed Polish-English ethnologist, told American readers that totalitarianism was nothing but the constitution of the nation on a wartime basis. But it was an American scholar, Harold Lasswell, who addressed himself to the problem in the greatest depth. Lasswell's vision was a native American precursor of the "Garrison State" as he termed it. In the garrison state, total war had totally obscured the traditional difference between a civilian and a military sphere of life. He predicted an energetic struggle, ostensibly in behalf of the common man, to incorporate the young and old into the mission of the state, singling out in particular the termination of unemployment as the most conspicuous form of propaganda to coerce the people. Lasswell, in fact, was describing a structure of society that was already regimented and haunted by a huge bureaucracy, although in principle it would retain the outward forms of democracy, and the sociologist admitted openly that his prediction was rooted in the contemporary American experience, resting upon "the extrapolation of past trends into the future." It not only could happen here, Lasswell was saying, but it had actually been happening for some time.

But America needed no warning from the 'experts.' 'The totalitarian regimes of the nineteen thirties were seen by a large number of observers in the United States as the children of the First World War. Out of that war, Missouri Senator Bennett C. Clark warned, came Hitler, Stalin and Mussolini. Republican leaders were now disposed to agree with Eugene Debs, the Socialist leader, who had once lamented that all America got out of that war was influenza and the income tax. The political left and right vied with each other in portraying the dire consequences of another war that in size and 
impact was certain to dwarf the first international conflagration. Almost unanimously, critics on both sides of the President subscribed to the view that U.S. participation in another war would not only be ineffective but would guarantee dictatorship in the United States overnight. So widespread were such views that, ironically, it is likely that Franklin D. Roosevelt privately shared them. War, he told Assistant Secretary of State Adolf Berle, could mean opening a Pandora's box that would release forces none of them would understand.

The notion that dictatorship had already arrived in the United States in a minor way made such viewpoints all the more compelling to the opposition. It was the dictatorial power that the Lend-Lease bill proposed to give to Roosevelt which aroused the fury of his opponents, not the principle of aid to Britain, a Republican insider observed. During the debate over the bill, conservative Democrats charged that the President would actually become an American Fuehrer if Lend-Lease became law, and the Republicans termed the proposal a streamlined declaration of war. Samuel Crowther, writing to other prominent Republicans, expressed his belief that Lend-Lease was designed to make a painless transition into that condition in which people were the slaves of the State. While there were important Republican leaders who feared that Lend-Lease was primarily another trick to fool the American taxpayer and in that way expand the old New Deal practices by putting all other countries on WPA as well, the main fear seemed to be the one voiced by Senator Vandenberg who felt that Lend-Lease would make Roosevelt "the Ace Power Politician of the World and ... turn the White House into G.H.Q. for all the wars of all the world." Charles Lindbergh believed this was Roosevelê's way of taking the center of the world stage away from Kitler. As the Chattanooga News had long since pointed out, Roosevelt would not become a dictator unless war came, hut Lend-Lease seemed in the eyes of the sceptics to bridge the gap from peace to wartime and hence make regimentation certain.

While there was general agreement among the critics that Mars would be the midwife of the new revolution, they were characteristically uncertain about its direction. Both sides agreed that it would entail all-out government control and nationalization of key industries as well as regimentation of labor. But the left was just as certain that the label that had to be affixed to the new order was Fascism as the right was convinced it had to be Socialism. One of the 
most influential analysts was Raymond Moley, a chief Roosevelt aide during his first term and later an important critic. Moley took a less ideologically committed view about the prospects. The New Dealers, he reasoned, would claim that to fight Hitler's movement, "which they call a world revolution, we shall need a counterrevolution. Not being very original or subtle people, they interpret such a counter-revolution as the exact opposite of Nazism - which is Communism, under another name, of course-and therefore we get the British Labor Party idea of a world cooperating commonwealth." Essentially, Moley believed the result would be an attempt to establish "throughout the world a still more radical New Deal, and as we have learned from our experience with the New Deal, it is something that needs to be supported by capitalistic money." Just as the New Deal was expected to be at heart either communistic, socialistic or fascist-and the American people, typified by Senator Harry S. Truman in 1941, did not find any major difference between them-it followed by applying the same logic in reverse that whatever -ism came out victorious in a world war it would also in large measure be a New Deal victory. The revolution emerging from a conflagration, in other words, would be an extended Roosevelt revolution.

Events in 1941 appeared to confirm such suspicions. When the President on May 27 proclaimed that a state of unlimited national emergency existed, this was interpreted as the climax of eight years of political extravagance. The following day, Secretary Ickes was named petroleum coordinator for national defense and thus succeeded, Rebublican leaders noted, in establishing precisely that control over the oil industry which the New Deal had sought in vain since it came into power. The only hope which Moley could offer his fellow sceptics was that while Roosevelt was by now sure to have an even greater variety of powers than President Wilson had had in the midst of World War I, there was always a chance that the President might forget some of them. At a time when the New Deal was ostensibly on the wane, the theme of Army and Nay Journal editor John O'Laughlin's informed and perceptive letters to GOP leaders was rather the triumphant New Deal revolution. He observed: "The out and out New Dealers are in the saddle, and they are using their power with the same zest they have exercised in the past."

The ascension of Harlan F. Stone to the position of Chief Justice of the United States became interpreted as a sign that the New Deal 
by June of 1941 had assumed control over all three branches of the government - even though Stone was known as a moderate and had been elevated to the highest court by Calvin Coolidge in 1925. As was known in congressional circles, Roosevelt at this stage entertained the hope that he could retain the services of Thomas $\mathbf{J}$. Corcoran, reputed to be one of the most dedicated but also one of the most Macchiavellian of the New Dealers. House Speaker Rayburn, however, vetoed a presidential suggestion that Corcoran be made Solicitor General in August 1941. Also, it had become clear that the members of the Supreme Court were divided on the matter. But if Roosevelt was forced to reluctantly part with Corcoran, lie did not bid farewell to Harry Hopkins, the former WPA administrator and Secretary of Commerce, who even more than Corcoran had antagonized sections of the Democratic party in 1940. In January 1941 Roosevelt made Hopkins his special messenger to Britain and later in the year officially designated him Special Assistant to the President. From then on and for the duration of the war, Hopkins served as Roosevelt's daily companion with a residence in the southwestern corner of the second floor of the White House itself. Even New Dealers now began to complain that everything had to seep through Hopkins in order to reach the President. Talk about the evil influence of this American 'Rasputin' abounded. To John Pritchard, Hopkins became the very symbol of New Deal II.

Such attitudes made it plausible to regard war as the conscious or near-conscious culmination of the New Deal-and vice versa. The amazing thing was not that the notion was conceived, but that it was so widely shared among Roosevelt's critics. It was Senator Burton K. Wheeler, the old progressive from Montana, who provided the most devastating suggestion of a link between the administration's new foreign policy and the New Deal of old by attacking Lend-Lease as "the New Deal's Triple A foreign policy; it will plow under every fourth American boy." More conservative voices like Bruce Barton, a Republican leader, proclaimed the establishment of the Tokyo-Berlin axis in the summer of 1940 as the New Deal's final triumph. And Senator Robert A.Taft, the conservative Republican from Ohio, stated in the same vein that "Entrance into the European war will be the next great New Deal experiment." More than that, such views were also privately and generally shared in congressional circles. As early as at the end of 1938, it was reliably reported that the more conservative Democrats, "including the 
V[ice] P[resident], and practically all of the Republicans, are suggesting that Roosevelt has taken the road to war in order that he may perpetuate himself in power." On October 24, 1941, eighteen Republican congressmen met secretly in the Willard Hotel in Washington to debate the problem of Wendell Willkie. All of them agreed, it was reported confidentially to ex-President Hoover, that the administration's foreign policy sprang directly from his domestic policy. Moreover, "they all had a deep-seated conviction that the administration was concerned with war not as war but as a method of destroying the present form of government in the United States."

The Japanese attack at Pearl Harbor on December 7, 1941, produced instant unity among all warring political factions in the United States. The red-hot irons of Mars seemed to have sutured the wounds of the past. Fear and even uncertainty drowned in a torrent of rightful indignation. The editors of Time pointed to a nation "in a state of granite certainty." Newsweek was amazed at the speed with which the internal discussions had been wiped out. Interventionist, isolationist, Republican, Democrat - those were all names which in the opinion of U.S. News had vanished in Pearl Harbor's smoke. Columnist James Reston told the readers of the New York Times that, almost miraculously, the deep divisions that had marked the nation's entrance into the wars of 1776, 1812, 1861, 1898 and 1917 were all absent. Indeed, on his sixtieth birthday on January 30, 1942, Franklin D. Roosevelt found himself at the highest point of public confidence since he took office in 1933, 72 percent of the people had backed their President immediately prior to the outbreak of the Pacific war, but by January the percentage had reached 84 and was still rising. Chicago police arrested young Edwin A. Loss, Jr. when he booed a sound movie showing the President, and before the judge fined him $\$ 200$ which was the maximum for disorderly conduct, the youngster explained that he did not realize what he had been doing. When unity finally arrived, it did so-it appeared - with a vengeance.

Both inside and outside of Congress, the nation's politicians revealed every intention of foregoing traditional politics. "There are no party lines today in Congress," it was noted after a state of war had been declared. "There are no blocs, no cliques, no factions. The house-divided-within-itself has ceased to exist in Washington." On December 10, Ed Flynn in his capacity as chairman of the Democratic National Committee wired his Republican counterpart Joseph Martin, asking for a complete moratorium on politics. Flynn 
suggested that the two agencies instead of being used for partisan advantage should be made available for the President for national defense. Martin responded favorably, if cautiously, saying that as before the GOP would not allow politics to enter into national defense matters. Roosevelt quickly moved in to seal the agreement, thanking the two organizations for their truce which he described as being for the duration of the emergency. The outcome was described as the most complete adjournment of politics since the formation of the two-party system.

But in fact nothing could have been more deceptive than the show of unity during the first months after December 7, 1941. Real unity ended, as it began, with Pearl Harbor. The war situation and Roosevelt's popularity made open opposition suicidal for his detractors. While they officially joined the chorus of non-partisanship, they were privately unreconstructed. The Socialists, Norman Thomas admitted, were simply biding their time. He did support the President of the United States, Charles Lindbergh reasoned, but he had no confidence at all in Roosevelt. Lindbergh sided with a large group of America Firsters who favored adjourning the activities of the organization rather than dissolving it. Hoover and Landon remained as profoundly distrustful of their old adversary: "Just remember," Landon warned a friend one week after Pearl Harbor, "that once a boondoggler always a boondoggler." Outwardly calm and cooperative, most congressional Republicans and many Democrats were privately helplessly furious.

The much-heralded removal of party politics by itself gave many Republican leaders cause for alarm. GOP chairman Martin had been taken by surprise by Flynn's initiative, but even so his reply was simply a reiteration of his pledge from 1940 to keep politics meaning no doubt New Deal politics - out of the defense effort. The sceptics now interpreted Roosevelt's moratorium on politics as a shrewd attempt to silence the opposition and establish a one-party government. It was the disappearance of politics and an overdose of unity, GOP publicity director Clarence Kelland declared on February 12, 1942, which in the past had produced the oppressive regimes in Germany, Italy and Japan. By the middle of February, the Republican party had decided that its main task, rather than indulge in patriotism, would be to "proclaim the necessity of politics."

One chief reason for the almost instant return of politics after Pearl Harbor was the simple fact that, unlike in Britain where 
elections had been postponed until after the war, the democratic processes would run their normal course in the United States. With 34 senators and all 435 members of the House of Representatives up for election in November 1942 politics was unavoidable. As U.S. Nens put it, "A Congress with the biggest job of any in history has collided with an election year." Both sides were jockeying for positions. Roosevelt might talk to his aide William Hassett about the evils of politics in wartime and dwell upon the unfortunate political maneuvers during the Civil War in particular, but even his rather perfunctory involvement in the gubernatorial battle in New York was interpreted as a sure sign of greater presidential ambitions. The contest was not only between the Democratic element and the Republican group which was headed by Thomas E. Dewey, the ultimate winner and presidential aspirant, but also between proand anti-Roosevelt factions - the latter with Jack Bennett as their candidate. Former Governor Al Smith saw it as "Roosevelt's beginning of a fight for a fourth term for himself" rather than an attempt to simply replace Bennett with Senator James M. Mead, a Roosevelt backer. Victory for the Roosevelt forces was believed to have enormous long-range consequences. "Maybe that is our destiny," the York Daily Nons pondered; "Maybe we are fated to change from republicanism to Caesarism."

It was, in fact, less of a return to normal politics than it was a recoil to the special high-intensity debate that had characterized the pre-war situation. As the statements by Smith and the Daily Nens indicate, the fears and suspicions regarding the New Deal remained unabated. Once aroused, they sustained in an important minority in Washington a climate of opinions that made the idea of a "New Deal of War" appear as convincing after December 1941 as prior to it.

Contrary to what the York Times was saying, Pearl Harbor had not completely exploded the myth that Roosevelt had sought to trick the nation into war. What convinced the vast majority of Americans served only to strengthen the suspicions of the irreconcilable The Japanese attack seemed too perfectly suited to rallying the nation behind a declaration of war. To offset such thinking, the President had appointed a commission headed by Supreme Court Justice Owen Roberts, no ardent backer of the New Deal, to investigate the circumstances of the attack. On January 24, 1942, the commission reported its findings which were later corroborated by the historians: the administration could not be blamed. Instead, 
the Roberts commission criticized Admiral H. E. Kimmel and General W. C. Short, the military area commanders involved. On February 28, it was announced that a court martial was in progress, although both officers were allowed to retire shortly thereafter. Such actions were not sufficient to dispel the accumulated animosities, however. The opposition had, in fact, foreseen the possibility of a "war-making incident," but in the autumn of 1941 believed that the American people would understand that it was the result of presidential machinations. On November 14, 1941, both Alf Landon and Norman Thomas spoke in almost identical words about the extreme bitterness of the common man when he found out that he had been tricked into the war. On December 11, two days after the attack, 20 of the 28 Senate Republicans met for a private conference which ended in a unanimous pledge of support in the war effort. What was not known at the time was that after a debate which turned around the issue of Pearl Harbor for nearly two hours, tempers ran so high that only at the last minute was it agreed to delete a phrase in the final resolution which would have amounted to a vicious indictment of the President. There were reports that Roosevelt was being shockingly abused even by former backers in the Middle West because of the belief that the war had been engineered by the White House.

Whether or not Roosevelt's opponents continued to subscribe to the view that the administration had made use of the war as a political weapon even to the point of involving the nation in actual warfare, they seemed entirely convinced that the President was determined to utilize the war situation once it had materialized as a shield for his reform schemes. War controls, it was contended, might well become the basis for a "Super-New Deal"; what the reformers had been denied in peacetime could now be pushed through in the name of national security. In an attack on the Board of Economic Warfare in the spring of 1942, the New York JournalAmerican asked warfare against whom and against what? "Is it warfare against the traditional 150-year old American economic way? ... Is it a WAR or a REVOLUTION that is going on in the United States?" The battle that raged over the Office of Civilian Defense in early 1942 underlined the same points. The OCD, which was co-directed by Mayor Fiorello La-Guardia and Eleanor Roosevelt, seemed to epitomize the view that Congresswoman Caroline O'Day had voiced in 1940: "Our social program is as much a part of national defense as our arms." On the theory that real defense 
had to be based on individuals having confidence in themselves, Mrs. Roosevelt encouraged physical fitness courses that provoked administration detractors just as much as the hiring by the OCD of presumed leftists. The agency's director, James M. Landis, protested that his was not a "social reform organization," but to the opposition the OCD was "just another sample of the way the New Deal operates."

The belief that there was what Alf Landon privately termed a "New Deal First" movement concerned many of Roosevelt's opponents to the point of obsession. With Samuel Crowther, they believed they were "in the grip of war and social theory." As Senator Ralph O. Brewster, a Maine Republican, saw it in 1943, "This is not fighting a war. It's pushing an ideology - the very ideology, as a matter of fact, that we are fighting with guns at the front." Roosevelt's wartime Secretary of Commerce, Jesse H. Jones, was convinced that the President was fighting two wars at the same time-one military and one political. The real enemy in the eyes of the administration, Alf Landon charged, was not Hitler but the wicked capitalist system. There was a significant small number of people, Roosevelt retorted privately, that would rather nail his hide to the barn door than win the war. One successful Republican office-seeker even boasted openly that he had gone after the President with as much venom as if there had been no war. Indeed, Herbert Hoover was told in 1942, "we find a purpose, not merely a disposition as in the past, to embarass and heckle the President."

The result was far-reaching. In nearly all other nations, the coming of the war had produced political cooperation in the face of external danger. In the United States, too, the effect of World War II was politically soothing to some extent, at least on the surface and in the nation as a whole. In Washington, however, rather than obliterate the political tension the war intensified it. Out of it came nothing less than a "war within the war." Both participants in the feuds and later historians have used the words "civil war" to describe the situation. "I regret to say," Federal Reserve chairman at the time, Marriner S. Eccles, said in looking back, for example, "that each of us who served in Washington during 1940- 45 fought a civil war within an international one." No doubt the war would end some day, Under Secretary of Commerce Will Clayton wrote a conservative friend in July of 1943, but the battle of Washington "perhaps never." Small wonder that Max Lerner at the end of that year-as Roosevelt was returning from Teheran after discussions 
about a second front against the Axis-could observe somewhat despairingly: "The President has come back to his own Second Front. We shall need to build another bridge of fire, not to link in with our Allies but to unite us with ourselves, and to span the fissures within our own national will."

Within less than two months after Pearl Harbor, past and present thus merged in American politics. The sheer longevity of the Roosevelt administration, the fear of its "real" aims coupled with resentment over its actual achievements, the creation-particularly after 1936-of what seemed to be more of a New Deal party than the traditional Democratic party - all this was further aggravated in the eyes of Roosevelt's opponents by a war which was in their view at best one that would incidentally promote the kind of society the New Dealers had tried in vain to bring about in peacetime and which was at worst one that had actively been engineered for that purpose by a reckless aspirant for dictatorial power in the White House. The activism of Roosevelt and his chief lieutenants and agencies during the war itself intensified the crusade against the New Deal and made it part of a war within the war. Yet even without that activism, the "New Deal of War" concept went a long way toward making something akin to a political civil war unavoidable. As one prominent Republican put it during World War II, the wartime crop of "dragon's teeth" had been planted during the years of Roosevelt's peacetime "trickery."

\section{NOTE}

This article is scheduled to appear in substantially the same form in the author's forthcoming book on the eclipse of the New Deal, 1940-1945, to be published by Alfred A. Knop Publishers of New York. For this reason, it has been deemed superfluous to include here the 180 sometimes extensive footnotes to the original text. 